\title{
LIABILITY OF REPORTING ISSUERS, DIRECTORS, MANAGEMENT AND RESERVES ENGINEERS FOR RESERVES REPORT ERRORS
}

\author{
DALlas L. DROPPO, Q.C. AND BRITTA WAGNER
}

Who is liable for errors in oil and gas reserves reports and to whom? In the wake of newly adopted reserves reporting requirements, the question of liability deserves critical examination. What are the responsibilities imposed by the new reserves reporting instrument called National Instrument 5/-10/? What is the potential scope of liability faced by reporting isswers, their directors and senior management and the independent reserves evaluators and auditors who are appointed to evaluate reserves data? How do reserves reporting requinements fit into the slatufory framework for public disclosure generally? What strategies can be adopled 10 limit liability and will they be effective? These and other questions are examined in this ariicle.
Qui est responsable des erreurs commises dans les rapports sur les réserves de pétrole el de gaz naturel. ef envers qui? Dans la foulée des nouvelles exigences adoptées en matière de rapports sur les résenves, la question de la responsabilité mérite un examen approfondi. Quelles sont les responsabilités imposées par le nouvel instrument de rapport appelé Instrument national $5 / .101$ ? Quel est le champ de responsabilité éventuel de ceux qui présentent les rapports, des directeurs el des membres de la haute direction ainsi que des evaluateurs et vérificateurs indépendants nommés pour évaluer les données des réserves? De quelle manière ces exigences conviennent-elles au cadre statutaire des réserves en général? Quelles sont les stratégies que l'on peut adopter pour limiter la responsabilite, et seront-elles efficaces? Ces questions et d'autres sont examinés dans cet article.

\section{TABLE OF CONTENTS}

I. INTRODUCTION $\ldots \ldots \ldots \ldots \ldots \ldots \ldots \ldots \ldots \ldots \ldots \ldots \ldots \ldots$ I

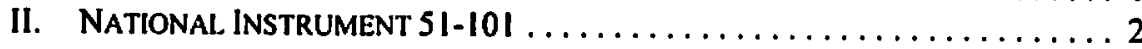

A. REPORTING ISSUER RESPONSIBILITIES $\ldots \ldots \ldots \ldots \ldots \ldots \ldots \ldots$

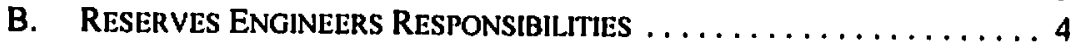

C. MaNAGEMENT AND DiRECTORS RESPONSIBILITJES $\ldots \ldots \ldots \ldots \ldots 5$

III. NATIONAL INSTRUMENT $51-101$ LIABILITY $\ldots \ldots \ldots \ldots \ldots \ldots \ldots 6$

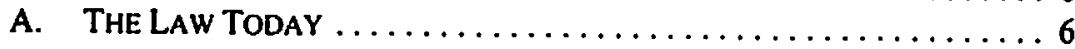

IV. Proposed Developments in the Law $\ldots \ldots \ldots \ldots \ldots \ldots \ldots \ldots \ldots$

A. New Civil Liabilities - Notice $53-302 \ldots \ldots \ldots \ldots \ldots \ldots . \ldots 17$

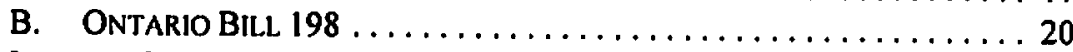

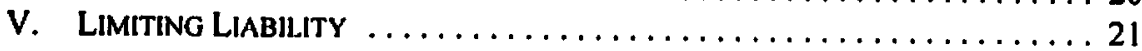

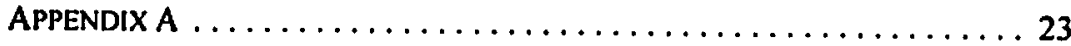

APPENDIX B ................................ 29

\section{INTRODUCTION}

Who is liable for errors in oil and gas reserves reports and to whom? This article answers both questions in light of changes to reserves reporting requirements and considers the scope of liability faced by reporting issuers, their directors and management and the independent

Bartisters and Solicitors, Blake, Cassels \& Graydon LLP. Calgary, Alberta. Special thanks to Alana Slager, articled student at Blake, Cassels \& Graydon LLP, for her assistance. This article is for informational purposes only and does not constitute legal advice. The opinions expressed herein are those of the authors only. 
reserves evaluators and auditors who prepare reserves data (together Reserves Engineers). Liabilities for errors in reserves reports, particularly liability to the investing public, is considered at common law, pursuant to securities, corporate and criminal law, and pursuant to changes in the law proposed by the Ontario legislature and the Canadian Securities Administrators (CSA). This article discusses the duties and responsibilities imposed by reserves reporting requirements, considers the potential causes of liability and concludes with a discussion of strategies for limiting the liability of issuers, directors, management and Reserves Engineers for reserves report errors.

\section{NATIONAL INSTRUMENT 51-101}

The Alberta Securities Commission (ASC) established an oil and gas task force in 1998 to make recommendations regarding the oil and gas disclosure policy known as National Policy Statement No. 2-B: Guide for Engineers and Geologists Submitting Oil and Gas Reports to Canadian Provincial Securities Administrators.' The product of the task force's recommendations to enhance the quality, consistency, timeliness and comparability of public disclosure of upstream oil and gas activities is National Instrument 51-101: Standards of Disclosure for Oil and Gas Activities. ${ }^{2}$ NI 51-101 came into force on 30 September 2003 and affects oil and gas issuers on the date they are next required to file audited financial statements or statements of reserves with a securities regulator. ${ }^{3}$ Although the genesis of the Instrument predated the auditing scandals in the United States, the Instrument is part of the world-wide trend to increase the scrutiny of public disclosure and governance practices.

Jo-Anne Bund, legal counsel to the ASC, in her recent presentation on $\mathrm{Nl} 51-101$ at the "3rd Annual Dialogue with Alberta Securities Regulators" put NI 51-101 in context when she noted the similarities between financial reporting and reserves reporting requirements. ${ }^{4} \mathrm{Her}$ presentation drew attention to the following parallels:

(1) both financial and reserves information must be reviewed by an expert, requiring an auditor to review financial information and a Reserves Engineer to review reserves information;

(2) the information must be the subject of the expert's report, which, for auditors, must be presented in accordance with the Canadian Institute of Chartered Accountants Handbook, and for Reserves Engineers must be presented in accordance with the Canadian Oil and Gas Evaluation Handbook:"

(3) boards of directors are required to delegate responsibility for oversight of auditors to a special audit committee of the board, a step that the board may take with

' Canadian Securities Administrators. 1982 (No. 2-B).

2 Canadian Securities Administrators, 2003 [NI $51-101$ or the Instrument].

1 Ibid.. ss. 9.1-9.2.

- Jo-Anne Bund, "National Instrument 51-101 Standards of Disclosure for Oil \& Gas Activities: Post Implementation Issues and Update" (Paper presented at 3rd Annual Dialogue with Alberta Securities Regulators, Metropolitan Conference Centre, 25 March 2004) [unpublished].

s Society of Petroleum Evaluation Engineers (Calgary Chapter) \& Canadian Institute of Mining. Metallurgy \& Petroleum (Petroleum Society), Canadian Oil and Gas Evaluation Handbook, vol. I (Calgary: Society of Peltoleum Evaluation Engineers (Calgary Chapler). 2002) [COGE Handbook]. 
respect to oversight of Reserves Engineers by delegating their responsibilities to a reserves committee;

(4) both kinds of disclosure require management to file a report attesting to their oversight of the collection and public disclosure of the information;

(5) financial information must be compared to the prior year and reserves information must be reconciled to the prior year;

(6) the deadline for public disclosure of the information is identical; and

(7) the information presented in the auditor's report is expected to be consistent with the reserves report, and vice versa.

While the similarities are substantial, there is a crucial difference from the perspective of executive officers filing financial as opposed to reserves information. Annual and interim financial statements are now required to be personally certified by the chief executive and financial officers of an issuer pursuant to Multilateral Instrument 52-109: Cerfification of Disclosure in Issuers' Annual and Interim Filings, ${ }^{6}$ which came into force on 30 March 2004.' The Companion Policy to MI 52-1098 specifically addresses the issue of liability for false certifications, pointing out that executive officers who make a false certification may be subject to private actions for damages, as well as quasi-criminal, administrative or civil proceedings under securities laws.'

In contrast to financial disclosure, reserves disclosure does not require personal certification, nor does the Instrument make a pronouncement with respect to liability. NI 51101 focuses on the role of issuers, their directors, management and Reserves Engineers in delivering accurate and timely information to the public market by setting out the content of reserves reports and reserves data, the parties responsible for the preparation and dissemination of reserves information and the standards to which reserves reporting is to adhere. Among the responsibilities created by the Instrument is the execution of forms confirming performance of the duties and responsibilities outlined, which forms are signed by officers on behalf of the issuer, and by directors on behalf of the board, and not by any of the parties in their personal capacity. In order to determine what the liabilities under NI 51 101 are, the Instrument must be evaluated in light of the responsibilities it creates and examined in the broader context of liability for public disclosure.

\section{A. REPORTING ISSUER RESPONSIBILITIES}

Parts 2 and 3 of NI 51-101 set out the responsibilities of reporting issuers with respect to oil and gas information, which is to file an annual statement of the reserves data specified in Form 51-101F1: Statement of Reserves Data and Other Oil and Gas Information ${ }^{10}$ as at the last day of the reporting issuer's most recent financial year and for the financial year then ended." In order to file Form 1, a reporting issuer must first comply with Part 3 of NI 51-101, which requires it to appoint one or more Reserves Engineers to prepare a report

Canadian Securities Administrators, 2004 [MI 52-109]

Ibid., s. 5.I.

Canadian Securities Administrators, Companion Policy 52-109CP to M1 52-109, 2003.

Ibid., Part 12.

Canadian Securities Administrators. 2003 [Form 1].

Ibid., s. 1.J. 
on the reporting issuer's reserves data. In order to be appointed, a Reserves Engineer must meet the requirements set out in NI 51-101, as well as those set out in the COGE Handbook.

To qualify for appointment, an individual must be a "qualified reserves evaluator" or "qualified reserves auditor" under NI $51-101$, which is defined as an individual who possesses the professional qualifications and experience appropriate for the estimation, evaluation and review (and in the case of auditors, audit) of reserves data and related information, and who is also a member of an approved professional organization. ${ }^{12}$ The securities regulatory authority in each provincial jurisdiction has the power to designate which professional organizations are acceptable based on: (1) whether they admit members primarily on the basis of their educational qualifications; (2) whether they require members to comply with professional standards of competence and ethics relevant to the estimation, evaluation, review or audit of reserves data; and (3) whether they have disciplinary powers, including the power to suspend or expel their members. ${ }^{13}$

Once a Reserves Engineer has been appointed, the reporting issuer is charged with the responsibility of supplying him with all the information reasonably necessary to enable him to provide a reserves report that both satisfies the requirements of Form 1 and is collected and evaluated in accordance with standards set out in the COGE Handbook.

\section{B. Reserves ENGINEERS ReSPONSIBILITIES}

Once appointed by a reporting issuer, NI 51-101 charges Reserves Engineers with the responsibility of expressing an opinion on the reserves data based on their audit, evaluation or review, confirming that this responsibility has been discharged by preparing Form 51-101F2: Report on Reserves Data by Independent Qualified Reserves Evaluator or Auditor ${ }^{14}$ and filing it with the securities commission in the applicable jurisdiction. Form 2 is addressed by the Reserves Engineer to the reporting issuer's board of directors and confirms that the reserves data is the responsibility of the reporting issuer's management. ${ }^{15}$ Form 2 also confirms that it is the Reserves Engineer's responsibility to express an opinion on the reserves data based on his audit, evaluation or review, to carry out this responsibility in accordance with the principles and definitions in the COGE Handbook and to obtain reasonable assurances that the reserves data are free from material misstatement. ${ }^{16}$ Form 2 must be filed together or concurrently with Form 1, as the fundamental rationale behind NI $51-101$ is to ensure that reserves reports are only filed with the applicable securities regulator when accompanied by the opinion of an independent expert.

Supra note 2, s. 1.I. Sections $1.1(x)$ and $(y)$ define "qualified reserves auditor" and "qualified reserves evaluator" respectively. To determine if a professional organization is acceptable for the purposes of NI SI-10I, the Alberta Securities Commission website <wnw. albertasecurities.com> provides a list under the following headings: Securities Law and Policy / Regulatory Instruments / N1 51-101. Ibid. Section1.1(w) defines "professional organization." Canadian Securities Administrators, 2003 [Form 2]. lbid. at 1 .

Ibid. 


\section{Management and DiRectors ResponsibiLities}

The most onerous responsibilities imposed by $\mathrm{NI} 51-101$ are placed on the shoulders of management and directors who are required to file Form 51-101F3: Management and Directors Report on Oil and Gas Disclosure ${ }^{17}$ attesting to the performance of their responsibilities. Form 3 must be signed by the reporting issuer's chief executive officer and another senior officer, as well as two directors of the reporting issuer, who thereby confirm that their respective responsibilities have been discharged. Management is required to acknowledge that it is responsible for the preparation of disclosure information with respect to the reporting issuer's oil and gas activities in accordance with securities regulatory requirements. The board of directors is required to acknowledge that it has discharged the following duties as set out in N1 51-101:

(1) reviewing, with reasonable frequency, the reporting issuer's procedures relating to the disclosure of oil and gas activities, including procedures for complying with the disclosure requirements and restrictions of NI 51-101;

(2) reviewing each appointment of independent Reserves Engineers and any proposed changes in such appointment;

(3) reviewing, with reasonable frequency, the reporting issuer's procedures for providing information to the Reserves Engineers;

(4) meeting with management and the Reserves Engineer to ensure that the reserves report can be provided without restrictions; and

(5) meeting with management and the Reserves Engineer to review and approve the content of the reserves report and reserves data in each of the forms to be publicly filed. $^{18}$

By signing Form 3, the board of directors confirms that it has approved the content and filing of the reserves data and other oil and gas information, the filing of the report of the Reserves Engineer on reserves data and the content and filing of Form $3 .{ }^{19}$ While the board is permitted to delegate some of its responsibilities to a reserves committee, provided a majority of the members are independent directors, ${ }^{20}$ the board is not permitted to delegate the responsibility for approving the content and filing of the information in Form 1 and Form $3 .{ }^{21}$ In addition, once a board has delegated permissible responsibilities to a reserves committee, it must solicit the recommendation of the reserves committee prior to filing Form $3{ }^{22}$

17. Canadian Securities Administrators, 2003 [Form 3].

ts Supra note 2, s. 3.4.

19 Supra note 17 at 2.

2o Supra note 2, s. 3.5(1). Section 3.5(1) requires the majority of the members of a reserves committee not to be and not to have been, in the preceding twelve months, officers or employees of the reperting issuer or its affiliates, or persons who beneficially own 10 percent or more of the outstanding voting securities of the reporting issuer, or a relative of such a person residing at such person's home, and requires them to be free from any business or other relationship which could reasonably be seen to interfere with the exercise of their independent judgment.

21 Ibid, s. 3.5(2).

$22 \quad$ lbid., 3.5(3). 


\section{NATIONAL INSTRUMENT 51-101 LIABILITY}

A respondent during the public consultation process regarding NI 51-101 expressed the view that the certification of the Forms discussed above exposed the signatories to excessive liability without adequate defences. The CSA responded to this allegation by publishing the following public comment:

\footnotetext{
One commenter stated that certification of Form 51-101F3 (Form 3) by two senior oflicers and two directors exposes them to a higher level of liability than exists in other Canadian industries and limits the defences available to them. Another commenter urged that we make clearer in Form 3 the differing responsibilities of management and directors... Form 3 is meant to confirm for readers the respective roles of management and directers and the process underlying corporate oil and gas disclosure. We believe that it does so. We are not persuaded that it exposes officers and directors to excessive or inappropriate liability or denies them appropriate defences. To the extent that civil liability arises under securities Iegislation, the relevant provisions also set out available defences. The CSA (other than the BCSC (British Columbia Securities Commission), which is not adopting Form 3) remain of the view that Form 3 will enhance market confidence in oil and gas disclosure and thereby indirectly serve the interests of reporting issuers $100 .^{23}$
}

Because reporting issuers are just now complying with the requirements of $\mathrm{NI} 51-101$, no case law yet exists on the scope of liability for NI 51-101 report errors.

\section{A. THE LAW TODAY}

Errors in reserves reports, whether negligently or deliberately made, will give rise to causes of action. Reserves Engineers may be sued by reporting issuers for breach of contract in preparing reserves reports; reporting issuers may be sued by investors for negligent misrepresentation; and directors and officers may be sued by shareholders for failure to comply with corporate and securities laws. The liability of most concern, however, is liability to the investing public, as reporting issuers are not the only parties at risk; rather, directors, officers, senior management and Reserves Engineers may each find themselves exposed to personal liability for reserves report errors.

The following discussion considers the potential causes of action that exist at law today for investors under the following legal categories:

(1) contract law for misrepresentation;

(2) tort law for negligent misrepresentation;

(3) securities law for misrepresentation and failure to comply with the law;

(4) corporate law for misrepresentation; and

(5) criminal law for fraud. 


\section{LiABILITY AT CONTRACT}

Contract law is the first area of law requiring consideration in determining a possible cause of action for errors in reserves reports. The case law regarding misrepresentation in a contractual context includes decisions on whether statements made by one contracting party to another form a term of the contract and, if such term is breached, decisions describing the scope of recoverable damages and other remedies, such as rescission.

There are two contracts in the reserves reporting schematic: the contract between the Reserves Engineer and the reporting issuer, where securities are issued from treasury, and the contract between the investor and the reporting issuer, pursuant to which the investor purchased the reporting issuer's securities.

It is industry practice, consistent with recommendations in the COGE Handbook, for Reserves Engineers to enter into an engagement agreement with a reporting issuer setting out the scope of the reserves review, the price for services and the responsibilities of each party. One of the responsibilities of Reserves Engineers is to carry out the review in accordance with standards set out in the COGE Handbook, followed by certifying that such standards have been satisfied by executing and delivering Form 2 . The engagement agreement together with Form 2 constitute the contract under which Reserves Engineers may be liable to reporting issuers for errors. The engagement agreement obliges the reporting issuer to provide the relevant information to the Reserves Engineer so that the Reserves Engineer may use the information in the preparation of the reserves report. If errors in reserves reports arise from inaccurate information provided by the reporting issuer, and the Reserves Engineer is not otherwise at fault, the reporting issuer will not have recourse against the Reserves Engineer under the engagement agreement. NI 51-101 demonstrates an awareness of the nature of this relationship as one of private contract, a legal measure that, as a result of privity of contract, may afford Reserves Engineers some protection for liability from the investing public. Furthermore, NI 51-101 prohibits a reporting issuer from publicly disclosing the reserves report, information derived from the report and the identity of the Reserves Engineer without the prior written consent of the Reserves Engineer. ${ }^{24}$ Privity of contract would not preclude a scenario where investors who purchase securities from the reporting issuer make a claim against the reporting issuer under the relevant subscription agreement (or based on one or more of the other causes of action discussed in this article) and in turn, where the reporting issuer makes a claim for breach of contract against the Reserves Engineers under the engagement agreement.

The purchase by an investor of a reporting issuer's securities from the reporting issuer is done by contract, typically a subscription agreement executed by the investor and reporting issuer pursuant to which the investor may be entitled to rely on the contents of a reserves report or a summary or excerpt thereof. Modern subscription agreements eliminate the uncertainty of whether statements in reserves reports constitute a representation made by the reporting issuer that forms a term of the contract by clearly making specific, express representations in the body of the contract and typically by adding a further clause stating that 
there are no representations made by the reporting issuer other than those expressly made. The representation in the body of the contract regarding reserve reports is often one that states that the public record (that is, the information filed with securities authorities), as it relates to the reporting issuer, did not contain any misrepresentations as of the date of the relevant information and no material changes have occurred since that date. This express representation would attach to publicly filed reserves reports and to publicly filed information derived from reserves reports, such that errors in the reserves reports may give rise to a breach of the subscription agreement. The typical subscription agreement includes an indemnity given by the reporting issuer to the other contracting parties and various other third parties (such as affiliates, directors, officers, employees, etc.), indemnifying these persons in respect of claims and damages arising from misrepresentation. The indemnity is usually broad and ensures that the scope of damages recoverable by the aggrieved investor is not limited by restrictive case law regarding recovery of damages for breach of contract.

From the perspective of the Reserves Engineer, and indeed from the perspective of directors and officers of reporting issuers, privity in the law of contract goes some way to insulate Reserves Engineers from liability to investors. This insulation does nothing, however, to protect Reserves Engineers or reporting issuers from the tort of negligent misrepresentation.

\section{LIABILITY IN TORT}

Next in the evolution of possible causes of action for errors in reserves reports is the tort of negligent misrepresentation. Negligent misrepresentation provides potential recourse by investors against a broader group of potential defendants, including the reporting issuer, directors, management and Reserves Engineers. This cause of action is discussed below for reporting issuers and Reserves Engineers (and is considered under corporate law for directors and officers later in this article).

In order to determine whether a reporting issuer will be liable for negligent misrepresentation for errors in reserves reports, the following questions must be answered in the affirmative:

(1) is there a duty of care based on a special relationship between the investor and the reporting issuer;

(2) is the representation in question untrue, inaccurate or misleading;

(3) did the reporting issuer act negligently in making the misrepresentation;

(4) did the investor rely, in a reasonable manner, on the misrepresentation; and

(5) did the reliance of the investor result in damages? ? $^{25}$

The answer to the question of whether there is a duty of care is easily answered in the affirmative, as evidenced by the creation of an entire statutory regime, namely securities legislation, surrounding the duty of care owed by reporting issuers to their investors. The second question, whether a representation is untrue, inaccurate or misleading, including by 
virtue of failing to disclose information, ${ }^{26}$ and the third question of whether a reporting issuer was negligent in making or failing to make the representations in question will turn on the facts of the particular circumstances.

It is usually the fourth question that causes problems for investors, being the issue of actual, reasonable reliance on the misrepresentation. In order to answer the fourth question in the affirmative, the investor will have to rely on the reserves report in making his purchase of securities. This will exclude investors who purchased before or well after the date of a negligently prepared reserves report, as they would not likely be able to establish reliance on the error-ridden report at the time of their purchase. This will be the case even though the investor can establish that the fifth question, being that the negligent reserves report caused the reporting issuer's stock to be devalued and subsequent damages, can be answered in the affirmative.

The sticky issue of reliance is subject to a further test (the Anns Test) from the often referred to decision of Anns v. Merton London Borough Council.27 The Anns Test reiterates that there must be a prima facie duty of care owed by the reporting issuer to the investor and the reporting issuer must be able to foresee that it is reasonable for the investor to act on the representations. The Anns Test, however, introduces an additional hurdle, requiring the court to consider if there is an overriding policy reason to limit the duty of care, the class of person to whom the duty is owed or the damages to which a breach of the duty may give rise. This public policy hurdle is founded on the need to avoid indeterminate liability to an indeterminate class for an indeterminate amount. Reporting issuers are unlikely to be relieved of liability under the policy arm of the Anns Test and are likely to be found liable for negligent misrepresentation in reserves reports; however, the Anns Test is a welcome shield in the defence of Reserves Engineers.

In Hercules Management $v$. Ernst \& Young, ${ }^{28}$ the defendant accounting firm was not found liable to investors for negligent misrepresentation in the preparation of audit reports in respect of companies that later became bankrupt. Although the accounting firm could foresee that shareholders would rely on their negligently prepared audit reports, the Supreme Court of Canada applied the Anns Test to determine that there were policy reasons to negate liability. The reasons given included the fact that the companies were required by statute to engage accountants to prepare audit reports, the audit was prepared pursuant to a private contract between the accountants and the companies and the principal purpose for which the audit was prepared was satisfied. The Court held that to find the accounting firm liable to investors who were using them to monitor their existing personal investments would have exposed accountants and all similarly situated defendants to liability from all classes of persons who may have occasion to rely on financial statements, resulting in the "indeterminate liability" against which the Court in Anns had warned. As La Forest J. wrote:

I would find that even though the respondents owed the appellants (qua individual claimants) a prima facic duty of care ... such prima facie duties are negated by policy considerations which are not obviated by the facts 
of the case. Indeed, to come to the opposite conclusion on these facts would be to expose auditors to the possibility of indeterminate liability, since such a finding would imply that auditors owe a duty of care to any known class of potential plaintiffs regardless of the purpose to which they put the auditors' report. This would amount to an unacceptably broad expansion of the bounds of liahility drawn by this Court in Haig. supra. ${ }^{29}$

Similarly, in Carom v. Bre-X Minerals Lid. ${ }^{30}$ the Ontario Court of Appeal did not find the engineering company engaged by $B r e-X$ to prepare its mining reports liable to investors for negligent misrepresentation. The reason given was that the engineering company prepared its reports pursuant to a private contract and was found to owe a duty of care to the mining company that engaged its services rather than the investing public, despite the fact that it was foreseeable that the investing public would rely on their reports.

The Hercules and Bre-X decisions may afford Reserves Engineers significant protection from liability to investors for negligently prepared reserves reports. Like financial auditors and mining engineers, Reserves Engineers prepare their reports pursuant to a private contract and owe their duty of care to the reporting issuer that engaged their services. However, fortunately for investors and unfortunately for experts, even the public policy grounds in the Anns Test may be overcome by statutory regimes created by provincial securities laws.

\section{LIABILITY UNDER SECURITIES LEGISLATION}

Securities legislation marks the next step in the evolution of the law with respect to liability for misrepresentations principally because it deems investors to have relied on misrepresentations in prospectuses, regardless of whether that is in fact the case, thereby circumventing the requirement of reliance developed pursuant to the common law of negligent misrepresentation. The Alberta Securities $A$ Cr" $^{31}$ defines a misrepresentation as: "(i) an untrue statement of material fact, or (ii) an omission to state a material fact that is required to be stated, or (iii) an omission to state a material fact that is necessary to be stated in order for a statement not to be misleading. ${ }^{32}$ Liability may arise for misrepresentations in reserves reports if the reports are filed under NI 51-101 with the ASC, or are included by reference (or as excerpts) in a prospectus or other offering document. The $A S A$ offences are outlined below, followed by consideration of the consequences and potential defences.

Reserves reports are amongst the materials that are required to be filed with the ASC, and reporting issuers who fail to file the forms required pursuant to NI 51-101 or who file untrue or misleading statements in reserves reports will expose the reporting issuer to liability. In addition, securities filings that fail to comply with applicable laws may also expose directors and officers to personal liability for the reporting issuer's failures as the general offences listed below apply to "any person or company" who: 
(1) makes a misrepresentation in respect of any material submitted or given under the $A S A$ to the Commission, its representative, Executive Director or any person appointed to make an investigation or audit under the $A S A$;

(2) makes a misrepresentation in any document required to be filed or furnished under ASA laws;

(3) fails to comply with the decision of the Commission or the Executive Director under the $A S A$;

(4) fails to file under the $A S A$, or to file within the time limits prescribed, any document, record or report required to be filed under the $A S A$;

(5) fails to comply with or is in contravention of a written undertaking made by that person or company to the Commission or the Executive Director;

(6) contravenes those provisions of the regulations made under s. 223 of the $A S A$ or the rules under s. 224 specified to be an offence if contravened; or

(7) contravenes a list of specific sections of the $A S A .^{33}$

If convicted, the penalties for securities offences may include a maximum prison sentence of up to five years less a day, a maximum fine of up to $\$ 1$ million dollars or both. ${ }^{34}$ With respect to misrepresentations, the $A S A$ does not distinguish between classes of persons who may be charged and convicted, and authorities may charge and convict directors, officers, management, Reserves Engineers and all others responsible for contravening the $A S A$.

To defend a charge of misrepresentation, a person will have to prove that he had no knowledge of the misrepresentation or, in exercising reasonable diligence, could not have known of the misrepresentation. ${ }^{35}$ A charge cannot be defended, however, on a basis of ignorance of the legal requirement in question, as the common law deems the offender to know the law.

Liability for misrepresentations is not only an offence under the $A S A$, but also exposes reporting issuers and their directors to potential liabilities to the investing public. Under the $A S A$, directors of a reporting issuer that proposes to offer securities pursuant to a prospectus have an obligation to ensure that the prospectus contains full, true and plain disclosure of all material facts relating to the securities being offered. ${ }^{36}$ Information about reserves reports unquestionably constitute material facts in relation to securities offered by an oil and gas issuer. Where a misrepresentation is found to exist in the prospectus or any documents to be included therein by reference, a purchaser is deemed by the $A S A$ to have relied on the misrepresentation. ${ }^{37}$ The investor will, furthermore, have a remedy in damages against the reporting issuer, its directors and any underwriter who signed the prospectus, as well as any person or company (for example, Reserves Engineers) whose consent has been filed with respect to a report, opinion or statement that has been made by them. ${ }^{38}$ The investor will also

$\begin{array}{ll}\text { 31 } & \text { Ibid., s. 194(1). } \\ \text { " } & \text { Ibid., s. 194(2). } \\ \text { is } & \text { Jbid., s. 194(3). } \\ \text { * } & \text { Jbid., ss. I16(1)-(2). } \\ \text { 31 } & \text { Ibid., s. 203(1). } \\ \text { 38 } & \text { lbid. }\end{array}$


have a right of rescission against the reporting issuer and each underwriter that signed the prospectus. ${ }^{39}$

The difficulty from the perspective of reporting issuers, directors, officers and Reserves Engineers is that the $A S A$ deems investors to have relied on a misrepresentation contained in a prospectus, regardless of whether or not that is in fact the case, and grants a right of action for damages or rescission for the misrepresentation even if the misrepresentation was not material to the investor's decision to invest. This marks a significant departure from the requirement to prove reliance under the common law test for negligent misrepresentation.

Directors' and officers' liability for misrepresentations in a prospectus are joint and several, meaning that each signatory to the prospectus is liable for the full loss of the investor, being the depreciation in the value of the security as a result of the misrepresentation. However, directors and officers will also have a right to recover a contribution from any person or company who, if sued separately, would have been liable for the same loss.

There are several defences available to a director or officer faced with liability for misrepresentation in a prospectus. The most important of these is the "due diligence" defence, whereby a signatory to the prospectus will be absolved of liability if he conducted an investigation of the facts so as to have reasonable grounds for a belief that there had been no misrepresentation and that he in fact believed that there had not been a misrepresentation. A person may also successfully defend a claim if:

(1) he can demonstrate that the purchaser in question had knowledge of the misrepresentation when the securities were purchased;

(2) the prospectus was filed without his knowledge or consent, and upon becoming aware of the filing, he gave reasonable general notice of such filing being made without his consent;

(3) he can demonstrate that, after the prospectus receipt was issued and prior to the sale of securities, he became aware of the misrepresentation and withdrew his consent and gave notice of such withdrawal and the reasons for it; or

(4) with respect to any expert portion of the prospectus, there were no reasonable grounds to believe and the director or officer did not in fact believe that there had been a misrepresentation. ${ }^{40}$

To avoid liability, directors and officers must demonstrate that they independently inquired as to the truth of documents and representations and did not simply rely on the representations and knowledge of others who provided information or authored offering documents." It will aid a director or officer to be able to demonstrate that he exercised a healthy degree of skepticism regarding material conclusions, conducted a reasonable investigation of the facts on which the conclusions in publicly disclosed documents rely, and personally examined the facts to verify that representations made were not false or 
misleading. ${ }^{42}$ In the absence of actions to verify and confirm material information, directors and officers may be held personally responsible for the losses suffered by investors. ${ }^{43}$ In Kerr v. Danier Leather ${ }^{44}$ the Court held the reporting issuer and certain individuals forming part of management liable for misrepresentation. The Court said inside directors will be held to a "stringent standard of reasonableness" in respect of diligence inquiries. ${ }^{45}$ Their liability "approaches that of the issuer as guarantor of the accuracy of the prospectus." 40

As stated, Reserves Engineers do not escape liability for misrepresentations in reserves reports filed with the ASC or included by reference in prospectuses and other offering documents. However, they will only be found liable for misrepresentations that appear in the portion of the prospectus that the Reserves Engineer was responsible for preparing or in a public filing that relied on his reserves data and to which he consented ${ }^{47}$ To defend against an action for misrepresentation in a prospectus, a Reserves Engineer may argue one of the following:

(1) that the investor knew of the misrepresentation at the time of investing;

(2) that the prospectus was filed without the Reserves Engineer's knowledge or consent;

(3) that the Reserves Engineer withdrew consent and gave reasonable general notice of the withdrawal;

(4) that the prospectus did not fairly represent the report, opinion or statement of the Reserves Engineer;

(5) that the Reserves Engineer had, after reasonable investigation, reasonable grounds to believe and did believe that the prospectus fairly represented his report, opinion or statement;

(6) that the Reserves Engineer, on becoming aware of the misrepresentation, gave the Commission and the public notice thereof and refused responsibility therefor; or

(7) that the Reserves Engineer had reasonable grounds to believe and did believe that the statement, report or document that contains the misrepresentation was true. ${ }^{48}$

If none of the possible defences outlined above succeeds, the Reserves Engineer in question is likely to be found jointly and severally liable for damages together with the reporting issuer, directors, officers and any underwriters.

In Danier Leather the issue arose as to whether a financial forecast can be a material fact (because the alleged liability was for misrepresentation of a material fact). Reserves Engineers express conclusions in their report in the form of an opinion. The opinion expressed by a Reserve Engineer will likely include implied assertions of fact for purposes of determining whether there has been misrepresentation of a material fact in reserves

R. v. Silver Bar Mines Lud. and Ronald A. Gilson (1992), 15 O.S.C. Bull. 3835.

Adams v. Thrifi, [1915] I Ch. 557.

[2004] O.J. No. 1916 (Sup. Ct. J.) (QL) [Danier Leather]

lbid. at para. 195.

Ibid. at para. 296.

Supra note 2, s. 5.7.

$A S A$, supra note 31 , ss. 203(4)-(5). 
reports. In Danier Leather the Court concluded that every promise includes implied assertions of fact. Factual assertions in a forecast include:

i. the forecast represents the forecaster's best judgment of the most probable set of economic conditions in the company's planned course of action ...;

ii. the forecast is sound and reliable in the sense that the forecaster made it with reasonable care and skill ...; and

iii. the forecaster generally believes the forecast, the forecaster's belief is reasonable and the forecaster is not aware of any undisclosed facts tending to seriously undermine the accuracy of the forecast. ${ }^{49}$

The Court went on to state that the forecast is "untrue" if it does not represent management's best judgment because:

i. the forecast was not prepared using reasonable care and skill; or

ii. management does not believe the forecast; or

iii. management's belief in the forecast is not reasonable; or

iv. management is aware of facts that would seriously undermine the forecast."

Each of the Court's comments would likely have application to Reserves Engineers in the formulation of their opinion in a reserves report.

No action may be commenced to enforce a cause of action created by the civil liability part of the Securities Act more than, in the case of an action for rescission, 180 days from the date of the transaction, or in the case of any action other than an action for rescission (that is, damages), the earlier of (i) 180 days from the date that the plaintiff first had knowledge of the facts giving rise to the cause of action, or (ii) three years from the date of the transaction that gave rise to the cause of the action."

In addition to the offence provisions of the $A S A$, the Executive Director also has broad administrative powers in the public interest under s. 197(1) to apply to the Court of Queen's Bench for a declaration that a person or company has not complied with a provision of the $A S A$. On application from the Executive Director, the Court may:

(1) impose a penalty or make an order to require the current directors and officers to be removed and replaced;

(2) require a person or company to compensate or make restitution to an aggrieved person or company;

(3) require a person or company to pay general or punitive damages; and

(4) require a person or company to pay the Provincial Treasurer any amounts obtained as a result of non-compliance with any provision of Alberta securities laws. ${ }^{\mathbf{5 2}}$ 
The Commission also has the power, after a hearing, to order a person to pay a penalty of not more than $\$ 100,000$ and a company not more than $\$ 500,000$, if at the hearing it is determined that a person or company has contravened or failed to comply with any provision of Alberta securities laws. ${ }^{\text {sJ }}$

\section{CORPORATIONS' ACTS}

While the $A S A$, like other provincial securities legislation, has legislated a fairly comprehensive regime with respect to liability for misrepresentations in public disclosure documents, a quick mention must be made of corporate law, particularly to set the obligations of the corporation and its directors and officers in context.

While a corporation has separate legal status distinct from the individuals who serve as its mind and management, this status is a legal fiction that offers some, but not ironclad, protection to corporate directors, officers and management. To be entilled to the protection afforded by separate legal status, directors and officers must, in exercising their powers and discharging their duties, "act honestly and in good faith with a view to the best interests of the corporation, and exercise the care, diligence and skill that a reasonably prudent person would exercise in comparable circumstances."

Directors and officers who fail to discharge their duties may find that the so-called "corporate veil" is pierced in order to hold them personally liable for the corporation's conduct and misconduct. This may be the case where directors' and officers' actions are conducted in bad faith, where they act outside the scope of their authority or where their actions are not for the benefit of the corporation. In short, to be protected by the veil of separate legal status, the actions of the directors and officers must be considered to be the actions of the corporation itself.

Directors and officers who make misrepresentations on behalf of and in the name of the corporation may be found personally liable for such misrepresentations. The Ontario Court of Appeal, by way of example, held corporate officers of both a parent and subsidiary company personally liable for deliberate and negligent misrepresentation, respectively, for providing incorrect corporate information to a bank in order to induce the bank to extend a line of credit. ${ }^{\text {ss }}$ The officer of the subsidiary company made a variety of deliberate misrepresentations in order to induce the bank to extend the line of credit, which misrepresentations were negligently confirmed by an officer of the parent company. The officers of both the parent and subsidiary argued that they were acting on behalf of their respective corporations in making the misrepresentations, but the Court determined that they independently owed a duty to the bank because they knew that the bank was relying on their representations and that their deliberate or careless actions could cause the bank to suffer a loss. 
Whereas directors may be found personally liable for negligent misrepresentations, directors who actively participate in a corporation committing an act of fraud will be found personally liable for the consequences. By way of example, directors who deliberately misrepresented the financial condition of the corporation they served in order to induce investment were found personally liable to investors for fraudulent misrepresentation in the amount of losses suffered by the misled investors. ${ }^{56}$

Corporate statutes do not set out a legislative regime for imposing liability upon experts, such as Reserves Engineers; however, corporate statutes do expressly permit directors and officers to delegate their authority to other parties and to rely on management and other professionals in certain circumstances. ${ }^{37}$ Reliance will even afford directors a limited defence to an alleged breach of fiduciary duty if the director can establish that he relied in good faith on an opinion or report of a lawyer, accountant, engineer, appraiser. or other person whose profession lends credibility to a statement made by him. $^{58}$

While delegation and reliance may provide boards of directors with some comfort in delegating responsibilities to experts such as Reserves Engineers, it is not a licence to abdicate their duties and responsibilities entirely. This concept is reiterated in NI 51-101 by permitting the board to delegate some of its responsibilities to a reserves committee of the board, but not the responsibility to approve the filing of a reserves report. ${ }^{50}$

\section{CRIMINAL LIABILITY}

Prior to considering proposed changes to the law, mention must be made of criminal liability for misrepresentation. Reserves reports that are not merely negligently prepared, but are fraudulently prepared with intent to defraud investors, and that do indeed defraud investors, will expose reporting issuers, directors, management, Reserves Engineers and all others with intent to commit fraud to criminal prosecution. A prosecutor who can prove that the fraud was committed intentionally and resulted in loss will likely seek a conviction for one of the following:

(1) fraud affecting the public markets;

(2) fraud in relation to a prospectus that is known to be false; or

(3) conspiracy to attempt to commit fraud. ${ }^{60}$

Convictions pursuant to these offences carry minimum imprisonment terms between two and ten years.

\section{Proposed Developments in the Law}

As discussed, negligent mistepresentation is the most likely grounds for an action against corporations, directors, officers and Reserves Engineers for errors in reserves reports

Ibid., s. 123(3).

Supra note 2, s. 3.5.

Criminal Code, R.S.C. 1985. c. C-46. ss. 380(2), 400(1), 465(1). 
prepared and filed in compliance with NI 51-101. A variety of grounds for suit are available to investors who purchase securities in reliance on negligently prepared reserves reports, but a gaping hole still exists in the legislative framework; namely, the right to damages for investors who purchase securities in the secondary market (that is, on a stock exchange). This gap may soon be filled by the introduction of proposed civil liabilities by the CSA and the Ontario legislature.

\section{A. New Civil Liabilities - Notice 53-302}

New civil liabilities are being considered by the CSA for recommendation to each of the provinces and territories pursuant to CSA Notice 53-302: Proposal for a Statutory Civil Remedy for Investors in the Secondary Market and Response to the Proposed Change to the Definitions of "Material Fact" and "Material Change, "61 which proposes to grant secondary investors the right to sue reporting issuers and certain key persons, including Reserves Engineers, for misrepresentations in public documents and, in the case of reporting issuers, for failure to make timely disclosure. ${ }^{62}$ The essence of the proposal is to provide secondary market investors a right of action to seek limited compensation for damages suffered if their purchase or sale of securities was made at a time when an untrue statement of a material fact has been made and not corrected, or when an issuer failed to make timely disclosure. That said, the primary purpose of the proposal is to deter issuers and key individuals responsible for making public disclosure from making misrepresentations in that disclosure. ${ }^{63}$ As stated in the executive summary to NI 53-302, compensation for investor damages is a secondary objective that must be balanced against the interests of long-term security holders of a reporting issuer "who effectively pay the costs of any damage awards." ${ }^{\text {"ts }}$ Consequently, $\mathrm{NI}$ 53-302 contemplates caps for different classes of responsible parties and proportions liability accordingly. ${ }^{63}$

As with liability for misrepresentations pursuant to a prospectus, NI 53-302 deems investors to have relied on a misrepresentation regardless of whether or not that is in fact the case, thereby reflecting the reality that a misrepresentation may have a detrimental effect on the market price of securities that affects an investor - even though that investor may not be able to prove that he or she relied on the particular misrepresentation in making the choice to invest in (or divest) publicly traded stock.

Under NI 53-302 an "expert" is defined as "a person or company whose profession gives authority to a statement made in a professional capacity by the person or company including, without limitation, an accountant, actuary, appraiser, auditor, engineer, financial analyst, geologist and lawyer." ${ }^{166}$ An expert will be liable if a document is released, or a statement orally made, containing a misrepresentation that was found in a report, statement or opinion made by the expert. Similarly, if a document or oral statement includes, summarizes or quotes from the report, statement or opinion of the expert and if the expert consented in

Ibid. at Appendix C "Civil Liability for Secondary Market Disclosure" at para. 2(4).

Supra note 61 at 1 .

Ibid.

Supra note 62 at paras. $4 \cdot 6$.

lbid. al para. I(1). 
writing to the use of the report, statement or opinion in the document or oral statement, the expert will also be liable. ${ }^{67}$

A reporting issuer's liability is capped at the greater of $\$ 1$ million or 5 percent of its market capitalization, and for an expert, liability is capped at the greater of $\$ 1$ million or the revenue that the expert and its affiliates earned from the responsible reporting issuer and its affiliates during the 12 months preceding the misrepresentation. ${ }^{68} \mathrm{NI} 53-302$ also contemplates a liability cap for national enforcement with a statutory limit on the total amount of damages received in each of the jurisdictions, making the liability of each defendant proportionate to that defendant's share of responsibility for the misrepresentation. A further exception exists in the event of a "knowing" misrepresentation that makes liability joint and several and removes the statutory liability caps that would otherwise apply.

The relationship between $\mathrm{NI}$ 53-302 (if it becomes law) and class action litigation requires brief examination, especially in light of the facts that the Alberta Class Proceedings $A c{ }^{69}$ was proclaimed in force on 1 April 2004 and British Columbia, Saskatchewan, Manitoba, Ontario, Quebec and Newfoundland already have class action legislation. If NI 53-302 becomes law, secondary market purchasers may be able to initiate class action suits that would otherwise be uneconomical to pursue and may also waive the common law requirement for there to be proof of reliance on the misrepresentation in question. In order for a group of litigants to be granted an order for a certification motion under the Class Proceedings Act, the court must be satisfied as to each of the following:
5(1) (a) the pleadings disclose a cause of action;
(b) there is an identifiable class of 2 or more persons:
(c) the claims of the prospective class members raise a common issue, whether or not the common issue predominates over issues afliecting only individual prospective class members:
(d) a class proceeding would be the preferable procedure for the fair and efficient resolution of the common issues;
(e) there is a person eligible to be appointed as a representative plaintiff who, in the opinion of the Court,
(i) will fairly and adequately represent the interests of the class.
(ii) has produced a plan for the proceeding that sets out a workable method of advancing the proceedings on behalf of the class and of notifying the class members of the proceeding. and
(iii) does not have, in respect of the common issues, an interest that is in conflict with the interests of other prospective class members. ${ }^{70}$

The executive summary attached to NI 53-302 discusses the concern of reporting issuers, especially large reporting issuers, to exposure pursuant to class action litigation. The CSA stated the following with respect to the issues raised: 
The CSA have carefully considered concerns raised in comments on the 1998 Draft Legislation and, before that, in the course of the deliberations of the Allen Committee, about the potential under the Proposal of exposing issuers and their long term shareholders to frivolous, coercive and costly litigation ("strike suits"). The concern, simply put, is that cost rules and other procedural protections included in the 1998 Draft Legislation would not deter plaintiffs from commencing merit-less actions with a view to extracting an early settlement. This is the most prevalent concern raised by lhose who oppose the Proposal.

The concern about strike suils must be addressed regardless of whether, and to what extent, one believes this will be the result if the legislation is adopted. Strike suits could expose corporalc defendants to proceedings that cause real harm to long-term shareholders and resulting damage to our capital markets.

The Allen Committee concluded that statutory civil liability for misleading continuous disclosure would have little effect without the mechanism of the class action suit. Throughout its deliberations, the Allen Committee focussed on the "strike suit" phenomenon in the U.S. in the securities litigation context. The Allen Committec compared the litigation environment in the U.S. to that in Canada and concluded that they are sufficienlly different 10 make it unlikely that merit-less class actions will be brought in Canada.

In response to comments received on the Interim Report, the Allen Committee again revietwed its recommendations and concluded that there was little practical risk that they would, if implemented, open the door to strike suits. Indeed, the Allen Committee was concerned that there are too many disincentives buill into the litigation system in Canada that tend to discourage even actions with merit. One example is the standard Canadian "loser pays" costs rules.

The CSA Civil Remedies Committee in 1998 had been largely persuaded by the Allen Report's conclusion that the litigation environment in Canada differs sufficiently from that in the United States that strike suits are not likely to be a problem in Canada. The depth of public concern on the part of the issuer community. however, coupled with some recent examples of entrepreneurial litigation in Canada, have led the CSA to recommend further measures to deter the potential for strike suils. ${ }^{7 !}$

The measures suggested by the CSA to deter class action litigation include requiring that the court approve any settlement between reporting issuers and a class of litigants initiating a class action law suit, and requiring the court to grant leave to potential litigants prior to bringing an action. The two measures suggested, when coupled with the requirements already imposed by the Class Proceedings $A C t,{ }^{72}$ go a long way to preventing frivolous claims, and even if the proposal becomes law, place a significant burden on investors who would like to rely on NI 53-302 to claim damages.

If the courts approve class action litigation for misrepresentations in reserves reports, reporting issuers, directors, officers, Reserves Engineers and all others responsible for reserves disclosure will be entitled to rely on the due diligence defence, which makes up part of NI 53-302. Of interest, NI 53-302 shifts the onus of proof to the investor to establish that the reporting issuer or other key person knew of the misrepresentation, deliberately avoided acquiring knowledge or was guilty of gross misconduct in making the statement that contained the misrepresentation.

$n$ Supra note 69. 
While NI 53-302 is still a proposal, reporting issuers and Reserves Engineers should request that their lawyers monitor its status in each of the jurisdictions and inform them if it becomes law as NI 53.302 has the potential to expand vastly the liability to investors for reserves report errors.

\section{B. ONTARIO BILL 198}

Ontario Bill $198^{73}$ received royal assent on 9 December 2002 to become the Keeping the Promise for a Strong Economy Act (Budget Measures), 2002. The portion that creates statutory rights of action for investors in the secondary market to commence actions against issuers, directors and officers, control shareholders and "experts" (which includes Reserves Engineers) has, however, not yet come into force. ${ }^{74}$ For the purposes of this article, only the portion of the Bill that has not yet been proclaimed will be referred to as Bill 198.

Bill 198 is based on NI 53-302 and if it becomes law, an investor who wishes to initiate an action will be required to prove that he has suffered losses derived from acquiring or disposing of securities while a misrepresentation (including the failure to make timely disclosure) went uncorrected. The investor will not be required to prove that he relied on the misrepresentation or obligation to make timely disclosure, as he will be deemed to have relied on the documents or statements containing the misrepresentation. However, an investor who knows of the misrepresentation at the time of the purchase or sale of the securities will not have a claim.

Investors will not be able to initiate an action without leave of a court granted upon motion with notice to each defendant. ${ }^{\text {s }}$ This is a mechanism designed to prevent frivolous claims in the hopes that an issuer will settle rather than go to court. The courts will look to ensure that actions are being brought in good faith and that there is a reasonable possibility that they will be resolved at trial in favor of the plaintiff. ${ }^{70}$

An investor will have a claim against a Reserves Engineer for damages where: (l) a document or oral statement is released and contains a misrepresentation in a report, statement or opinion made by the expert; (2) the document or oral statement includes, summarizes or quotes from the report, statement or opinion of the expert; and (3) if the document or statement was released by a person or company other than the expert, the expert consented in writing to the use of the report, statement or opinion in the document or oral statement."

In the case of actions against persons or companies other than experts, the investor will have to prove that the person or company knew of the misrepresentation, that the person or

7

An Act to implement Budget measures and other inisialives of the Government. 3d. Sess., 37th Leg., Ontario, 2002 (assented to 9 December 2002), S.0. 2002, c. 22.

"I J bid., cl. 185, s. 138.I. Section 138.1 defines an "expert" as "a person or company whose profession gives authority to a statement made in a professional capacity by the person or company including, without limitation, an accountant, actuary, appraiser, auditor, engineer, financial analyst, geologist or lawyer."

Ibid., cl. 185, s. 138.8(1).

Ibid., cl. 185, ss. 138.8(I)(a)-(b).

lbid., cl. 185, ss. 138.3(1)(c), 138.3(3)(f). 
company deliberately avoided acquiring knowledge that the document or public oral statement contained the misrepresentation, or that the person or company was, through action or failure to act, guilty of gross misconduct in connection with the release of the document or the making of the public oral statement that contained the misrepresentation. ${ }^{78}$ However, a plaintiff will not be required to prove these items in respect of a proceeding in relation to an expert. ${ }^{79}$

As with Notice 53-302, liability for a Reserves Engineer would, if he did not knowingly make the misrepresentation, be limited to a cap of the greater of $\$ 1$ million or the revenue he made from the reporting issuer and its affiliates in the 12 months preceding the misrepresentation. ${ }^{80}$ An expert who is defending an action may be relieved of liability if he can establish that he conducted reasonable due diligence and had no reason to believe that: (1) the document or statement contained the misrepresentation; or (2) that there was a material fact that was required to be disclosed. ${ }^{81}$

While Bill 198 is an Ontario bill, it will apply to reporting issuers in other jurisdictions whose shares are listed on the TSX or the TSX Venture Exchange. ${ }^{82}$ If adopted, Bill 198 will also apply to issuers that are not reporting issuers in Ontario, but do report in other provinces by virtue of the connection to Ontario through the TSX and TSX Venture Exchanges.

\section{LIMITING LIABJLITY}

Certainly the law has developed a minefield of potential liabilities for the parties responsible for public disclosure documents. However, those who are cautious and thorough in their preparation of such documents are very unlikely ever to have to defend an action for misrepresentation in a reserves report on behalf of a reporting issuer, or worse, themselves. The good news is that evidence of due diligence is likely to be a satisfactory defence to all the various causes of actions discussed. Now is the right time for boards, in particular, to review their governance practices with respect to oversight of their reserves reporting practices, as well as reviewing the terms of their issuer's private retainer or engagement agreements with their Reserves Engineers.

To make out a due diligence defence, a reporting issuer should first ensure that it carefully selects directors, officers and Reserves Engineers who are fully cognizant of their duties and responsibilities, who take those duties and responsibilities seriously and who are willing to take proactive steps to monitor the accuracy of information that is collected, interpreted and publicly disclosed. In making the difficult choice of who to appoint to the board, existing boards are advised to consider the "best practices guidelines" published by a range of investor protection groups, such as the Canadian Coalition on Good Governance and the Canadian Board Index, as well as consulting securities law guidelines and recommendations of the exchanges on which their securities are listed. Significant and growing emphasis is being placed on the independence of board members and on their experience and expertise.

Ibid., cl. 185, s. 138.4(1).

Jbid., cl. 185, s. 138.4(2).

Jbid., cl. 185, s. 138.1 .

Ibid., cl. 185, s. 138.4(6).

Securities $A c t$, R.S.O. 1990 , c. S-5, s. l(I)(c). 
Oil and gas issuers are therefore well advised to stock their board with directors who are knowledgeable about the oil and gas industry generally, and reserves evaluation specifically, by virtue of their education or experience.

An additional step that will aid in making out a due diligence defence is following the recommendations of the CSA with respect to reserves report preparation. The CSA recommends that boards delegate their NI $51-101$ responsibilities to a fully or mostly independent committee of the board - at least one member of which has reserves evaluation experience. The reserves committee should be governed by a charter that sets out the responsibilities of the committee for reviewing the qualifications of Reserves Engineers, reviewing the sources and reliability of reserves data provided by the reporting issuer, and reviewing the reserves report and making a recommendation with respect to its filing. In particular, reserves committee charters should set out the criteria for appointment of Reserves Engineers, as a reporting issuer who fails to inquire and confirm those qualifications and experience will have difficulty making even a threshold argument that it was duly diligent in the event that its particular Reserves Engineers are found to be negligent in the performance of their duties.

For additional guidelines, reserves committees should look to the COGE Handbook, which sets out reserves committee duties and responsibilities that should be included. Specifically, the appointment of Reserves Engineers and their retention pursuant to a private agreement should set out the tasks to be performed, the information to be provided and reviewed and the responsibilities each has for the communication and use of reserves information. ${ }^{83}$ The reserves committee charter should also provide the procedure for disclosing information to Reserves Engineers and the responsibility for periodically reviewing those procedures to ensure that the transfer of information is complete and accurate. Most importantly, the reserves committee charter should establish a policy with respect to open communication between Reserves Engineers and the reserves committee, both during the preparation phase of reserves reports and during the approval process. In-person meetings are also a good idea to ensure that reserves reports have been prepared in accordance with NI 51-101 requirements. A sample Reserves Committee Charter is attached hereto as Appendix A.

Reserves Engineers who are diligent both in the preparation of reserves data and in providing their consent to its use in public disclosure documents will be afforded significant protection from liability to investors, particularly so if they follow both the requirements and the recommendations set out in the COGE Handbook. Another strategy Reserves Engineers should consider to reduce their risk of suit for reserves report errors is to guard carefully against the inclusion of their reports and opinions in other disclosure documents. One particular means of reducing the opportunity for suit is to require investors who purchase securities of a reporting issuer pursuant to a subscription agreement to acknowledge the limits of liability contained in the reserves reports and opinions that they consent to file. Sample language that can be added to a subscription agreement to protect Reserves Engineers is attached hereto as Appendix B. Now is also the time for Reserves Engineers and their legal counsel to review standard form retainer or engagement agreements to ensure that they reflect the protections offered to them by NI 51-101. A repetition of the responsibilities of the 
reporting issuer and its directors and officers versus those of the Reserves Engineers is a worthwhile step to take to protect Reserves Engineers from liability.

While the potential liabilities may seem vast to reporting issuers, directors, management and Reserves Engineers, liability at contract, tort, pursuant to securities and corporate law, criminal law and even proposed changes in the law may be avoided by proper adherence to the responsibilities set out in NI 5I-10I and to the strategies recommended herein to limit, if not altogether avoid, liability. Reporting issuers, directors and officers should provide their reserves committee charter (if any), reserves communication's policies, director approval processes and retainer or engagement letters with Reserves Engineers to their solicitors for review. Legal counsel will be able to review the practices currently in place, make suggestions for improvements and if requested, provide an opinion on the adequacy of the mechanisms in place to ensure compliance with N1 $51-101$.

\section{APPENDIX A}

\section{PART I}

\section{Reserves Audit CoMmitTte Charter}

\subsection{Committee}

The Reserves Audit Committee (the Committee) is established by the Board of Directors (the Board of Directors) of ? Corporation (the Corporation) to assist the Board of Directors in fulfilling its responsibilities relating to the disclosure of information with respect to the Corporation's oil and gas activities and reserves data and the evaluations or audits of the reserves of the Corporation.

\subsection{Composition of Committee}

The Committee shall consist of as many members as the Board of Directors shall determine, but in any event not fewer than three directors, provided that each member of the Committee shall be determined by the Board of Directors to be:

(a) an independent director for the purposes of and pursuant to the Corporation's Corporate Governance Guidelines;

(b) an "unrelated" and "independent" director as defined in and for the purposes of any applicable governance guidelines or listing standards of any stock or securities exchange upon which the securities of the Corporation are from time to time listed; and

(c) an "independent" director for the purposes of any applicable corporate, securities or other legislation or any rule, regulation, instrument, policy, guideline or interpretation under such legislation.

A majority of the members of the Committee must be individuals who are not and have not been, during the preceding 12 months, an officer or employee of the Corporation or of an affiliate of the Corporation, a person who beneficially owns 10 pecent or more of the 
affiliate of the Corporation, a person who beneficially owns 10 pecent or more of the outstanding voting securities of the Corporation, or a relative of any of the foregoing persons residing in the same house as that person.

\subsection{Appointment of Committee Members}

The members of the Committee shall be appointed by the Board of Directors on the recommendation of the Corporate Governance \& Nominating Committee. The members of the Committee shall be appointed annually at the time of each annual meeting of shareholders, and shall hold office until the next annual meeting, or until they are removed by the Board of Directors or until their successors are earlier appointed, or until they cease to be directors of the Corporation.

\section{PART II}

\section{Committel Procedure.}

\section{$2.1 \quad$ Vacancies}

Where a vacancy occurs at any time in the membership of the Committee, it may be filled by the Board of Directors on the recommendation of the Corporate Governance \& Nominating Committee, and shall be filled by the Board of Directors if the membership of the Committee is fewer than three directors. The Board of Directors may remove and replace any member of the Committee.

\subsection{Committee Chair}

The Board of Directors upon recommendation of the Corporate Governance \& Nominating Committee shall appoint a Chair (the Chair) for the Committee. The Chair may be removed and replaced by the Board of Directors.

\subsection{Absence of Chair}

If the Chair is not present at any meeting of the Committee, one of the other members of the Committee present at the meeting shall be chosen by the Committee to preside at the meeting.

\subsection{Secretary of Committee}

The Committee shall appoint a Secretary who need not be a director of the Corporation.

\section{$2.5 \quad$ Regular Meetings}

The Chair, in consultation with the Committee members, shall determine the schedule and frequency of the Committee meetings, provided that the Committee shall meet at least [four] times per year. The Committee at any time may, and at each regularly scheduled Committee meeting shall, meet without management present. 


\subsection{Special Meetings}

The Chair, any two members of the Committee or the Chief Executive Officer of the Corporation may call a special meeting of the Committee.

\subsection{Quorum}

A majority of the members of the Committee, present in person or by telephone or other telecommunication device that permits all persons participating in the meeting to speak to each other, shall constitute a quorum.

\subsection{Notice of Meetings}

Notice of the time and place of every meeting shall be given in writing or by e-mail or facsimile communication to each member of the Committee at least 48 hours prior to the time fixed for such meeting; provided, however, that a member may in any manner waive a notice of a meeting and attendance of a member at a meeting is a waiver of notice of the meeting, except where a member attends a meeting for the express purpose of objecting to the transaction of any business on the grounds that the meeting is not lawfully called.

\subsection{Agenda}

The Chair shall develop and set the Committee's agenda, in consultation with other members of the Committee, the Board of Directors and management of the Corporation. The agenda and information concerning the business to be conducted at each Committee meeting shall, to the extent practical, be communicated to the members of the Committee sufficiently in advance of each meeting to permit meaningful review.

\subsection{Delegation}

The Committee shall have the power to delegate its authority and duties to subcommittees or individual members of the Committee as it considers appropriate.

\subsection{Access}

In discharging its role, the Committee shall have full access to all books, records, facilities and personnel of the Corporation.

\subsection{Attendance of Officers at a Meeting}

At the invitation of the Chair, one or more officers or employees of the Corporation may, and if required by the Committee shall, attend a meeting of the Committee. 


\subsection{Procedure, Records and Reporting}

The Committee shall fix its own procedure at meetings, keep records of its proceedings and report to the Board of Directors when the Committee may deem appropriate (but not later than the next meeting of the Board of Directors).

\subsection{Outside Consultants or Advisors}

The Committee, when it considers it necessary or advisable, may retain, at the Corporation's expense, outside consultants or advisors to assist or advise the Committee independently on any matter within its mandate. The Committee shall have the sole authority to retain and terminate any such consultants or advisors, including sole authority to approve the fees and other retention terms for such persons.

\section{Part III}

\section{Mandate OF COMmitree}

\subsection{Appointment of Corporation's Independent Qualified Reserves Evaluator or Auditor}

Subject to confirmation by the independent qualified reserves evaluator or auditor (the Evaluator or the Auditor) of its compliance with Canadian regulatory requirements, the Committee shall recommend to the Board of Directors the appointment of one or more Evaluators or Auditors for the purpose of estimating, evaluating, reviewing and, if applicable, auditing the Corporation's reserves data and related information. The Committee shall also recommend to the Board of Directors the approval of fees to be paid to each Evaluator or Auditor for its services.

The Committee shall be directly responsible for the retention and oversight of the work of each Evaluator or Auditor (including resolution of disagreements between management of the Corporation and an Evaluator or Auditor regarding the reporting of reserves data) for the purposes of preparing or issuing a report regarding reserves data or related work. Each Evaluator or Auditor shall report directly to the Committee.

The Committee shall review and evaluate the professional qualifications, experience, performance and independence of each Evaluator or Auditor, including a written report from the Evaluator or Auditor respecting its independence and consideration of applicable Evaluator or Auditor independence standards. The Committee should further consider whether, in order to assure continuing independence, there should be a regular rotation of the independent qualified reserves evaluator or auditors retained by the Corporation.

\subsection{Specific Mandates}

The Committee, to the extent required by applicable laws or rules, or otherwise considered by the Committee to be necessary or appropriate, shall: 
(a) Review and discuss with management of the Corporation and each Evaluator and recommend to the Board of Directors for approval:

(i) the content and filing of the statement of reserves data and other oil and gas information (the Statement of Reserves Data);

(ii) the filing of the report of the Evaluator or Auditor (the Report) regarding the evaluation or audit and review of the Corporation's reserves data;

(iii) the content and filing of the report of management and directors in respect of the Statement of Reserves Data and the Report;

(iv) the portions of the annual information form containing reserves data and oil and gas activities;

(v) any significant reserves data or information regarding oil and gas activities respecting the Corporation contained in any other public disclosure document or offering document;

(b) review and discuss with management of the Corporation and each Evaluator or Auditor each press release which contains significant reserves data or information regarding oil and gas activities respecting the Corporation;

(c) review, with reasonable frequency, the Corporation's procedures relating to the disclosure of information with respect to oil and gas activities and reserves data, including its procedures for complying with the applicable regulatory requirements and restrictions;

(d) ensure that disclosure in respect of reserves data and oil and gas activities made by or on behalf of the Corporation to the public, or which will become available to the public, or in any document filed with a regulatory authority complies with the applicable regulatory requirements and restrictions;

(e) ensure written consents are obtained from each Evaluator or Auditor in connection with the disclosure of a Report or any information derived from a Report or the disclosure of the identity of the Evaluator or Auditor;

(f) review with management of the Corporation and each Evaluator or Auditor the effect of regulatory initiatives on the reporting and disclosure of the Corporation's reserves data and oil and gas activities;

(g) ensure all information reasonably necessary to enable an Evaluator or Auditor to provide a Report that will satisfy the applicable regulatory requirements is made available to each Evaluator or Auditor;

(h) review, with reasonable frequency, the Corporation's procedures for providing information to the Evaluator(s) or Auditor(s);

(i) meet with management of the Corporation and each Evaluator or Auditor to determine whether any restrictions affect the ability of the Evaluator(s) or Auditor(s) to report on reserves data without reservation;

(j) review with management of the Corporation and each Evaluator or Auditor the reserves data and each Report thereon;

(k) review with management of the Corporation and each Evaluator or Auditor major issues regarding reserves evaluation and audit principles and practices as well as the adequacy of internal controls and procedures for reporting reserves data and oil and gas activities;

(1) review the plans of management of the Corporation and each Evaluator or Auditor regarding any significant changes in evaluation or audit practices or policies and the impact thereof; 
(m) review annually each Evaluator or Auditor's formal written statement of independence delineating all relationships between itself and the Corporation and review all such relationships;

(n) review the experience, qualifications and performance of the applicable members of each Evaluator or Auditor;

(o) review and evaluate each Evaluator or Auditor;

(p) in the case of any proposed change in the appointment of an Evaluator or Auditor, determine the reasons for the proposal and whether there have been disputes between the appointed Evaluator or Auditor and management of the Corporation;

(q) review with each Evaluator or Auditor the adequacy and appropriateness of the reserves calculation used in preparation of the Report;

(r) establish procedures for: (a) the receipt, retention and treatment of complaints received by the Corporation regarding evaluation or audit matters; and (b) the confidential, anonymous submissions by employees of the Corporation of concerns regarding questionable evaluation or audit matters; and

(s) periodically review the Corporation's public disclosure policy.

\subsection{Review of Disclosure}

The Committee shall review those portions of the Corporation's disclosure documents containing significant information relating to matters within the Committee's mandate.

\subsection{Review of Committee's Charter}

The Committee shall assess the adequacy of this Charter on an annual basis and recommend any changes to the Board of Directors.

\subsection{Non-Exhaustive List}

The foregoing list of duties is not exhaustive, and the Committee may, in addition, perform such other functions as may be necessary or appropriate for the performance of its responsibilities.

\subsection{Oversight Function}

While the Committee has the responsibilities set out in this Charter, the members of the Committee are members of the Board of Directors appointed to provide broad oversight of the Corporation's activities and affairs and are specifically not accountable or responsible for the day-to-day activities, nor the administration or implementation of arrangements relating thereto. 


\section{APPENDIX B}

\section{SUBSCRIPTION AGREEMENT ACKNOWLEDGEMENT}

The Subscriber acknowledges (on its own behalf and, if applicable, on behalf of each person on whose behalf the Subscriber is contracting) that it has read and understands the Terms and Conditions (the Terms and Conditions) set out in Appendix ? to the Reserves Report of [Insert the Reserves Evaluator or Auditor's name or company name] dated ? included as Appendix ? to the [Insert the kind of offering document] (the ?) and that in making this subscription it acknowledges and accepts the Terms and Conditions. Key elements of the Terms and Conditions include: [Adjust to wording of appendix]

(a) the disclaimer of implied warranties in the Standard of Care section;

(b) the limitation against distribution of materials to third parties; and

(c) the section entitled Limitations of Rights and Remedies.

The Subscriber acknowledges and agrees that it will accept the applicable sections of the Terms and Conditions in regard to its use of the Reserves Report with the same limitations as are applicable to the Corporation as a result of the Terms and Conditions.

The Subscriber further acknowledges and agrees (on its own behalf and, if applicable, on behalf of each person on whose behalf the Subscriber is contracting) that [Insert the Reserves Evaluator or Auditor's name or company name] is the beneficiary of, and is entitled to rely upon, this paragraph number?. 